\title{
KUALITAS AIR BUDIDAYA UDANG VANAMEI DENGAN Bacillus megaterium DAN Bacillus aquimaris
}

\section{WATER QUALITY FOR CULTIVATING VANAME SHRIMP WITH Bacillus megaterium AND Bacillus aquimaris}

\author{
Nadya Adharani ${ }^{1)}$, Megandhi G Wardhana ${ }^{1)}$, dan Restiani Sih Harsanti ${ }^{2}$ \\ ${ }^{1)}$ Program Studi Teknologi Hasil Perikanan Universitas PGRI Banyuwangi, \\ ${ }^{2}$ Program Studi Teknologi Hasil Pertanian Universitas PGRI Banyuwangi \\ Email:nadya.adharani@gmail.com
}

diterima : 5 Februari 2019; dipublikasi : 30 Maret 2019

DOI: http://dx.doi.org/10.32528/bioma.v4i1.2652

\begin{abstract}
ABSTRAK
Penelitian ini bertujuan untuk memperbaiki kualitas air budidaya udang vaneme dengan sistem bioflok menggunakan dua jenis bakteri laut asal cilacap yaitu Bacillus megaterium dan Bacillus aquimaris, dimana terdapat 4 perlakuan dengan 3 ulangan. Hasil yang diperoleh bahwa dengan budidaya sistem bioflok lebih baik dibandingkan konvensional dalam menurunkan limbah organik. P2 adalah perlakuan paling efektif dalam menurunkan kadar amonia, nitrat, dan nitrit, dengan prosesntase sebesar $35 \%$ untuk amonia, $61 \%$ untuk nitrat, dan penurunan $27 \%$ untuk nitrit. Melalui sistem bioflok lebih efektif dan berpengaruh terhadap panjang dan bobot pada udang dibandingan tanpa sistem bioflok. Bahwa P2 menghasil panjang dan bobot yang lebih besar diantara perlakuan lainnya dengan rerata panjang sebesar $9.2 \mathrm{~cm}$ dan rerata bobot sebesar 4.6 gr.
\end{abstract}

Kata kunci: Kualitas air, udang vanamei, Bacillus megaterium, Bacillus aquamaris

\section{ABSTRACT}

This research aims to improve the water quality of cultivating shrimp vaneme with bioflok system uses two types of marine bacterial origin of cilacap are Bacillus megaterium dan Bacillus aquimaris, where there are 4 treatment with 3 replicates. The results obtained with cultivation systems that bioflok better than conventional lowering organic wastes. P2 is the treatment most effective in lowering levels of ammonia, nitrates, and nitrites, with the prosesntase of $35 \%$ to $61 \%$ for ammonia, nitrate, and decreased $27 \%$ to nitrite. Through the system more effective and influential bioflok against long and weights on a shrimp compared without bioflok system. That P2 menghasil length and larger weights among other treatments with average length of 9.2 $\mathrm{cm}$ and average weight of $4.6 \mathrm{gr}$.

Keywords : Water quality, Vanamei shrimp, Bacillus megaterium, Bacillus aquamaris 


\section{PENDAHULUAN}

Buangan lingkungan budidaya berupa limbah organik dari sisa pakan buatan (pelet) dan feses hasil pemeliharaan udang vaname, akan berdampak negatif bagi pertumbuhannya. Hal tersebut terjadi jika bahan organik menumpuk dan mengendap di dasar media pemeliharaan dan tidak terdekomposisi, sehingga media pemeliharaan akan terurai secara anaerob kemudian membentuk efek toksik seperti amonia. Untuk mengurangi limbah organik dan buangan limbah dari lingkungan budidaya diperlukan sistem pengelolaan budidaya. Salah satu dengan sistem yang tidak asing lagi yakni sistem bioflok. Aktivitas bakteri merupakan salah satu agen biologis dalam proses dekomposisi bahan organik. Seiring dengan perkembangan pengelolaan budidaya melalui pendekatan biologis, telah diterapkan teknologi bioflok untuk menjaga kualitas perairan budidaya.

Bioflok merupakan teknologi penggunaan bakteri yang dapat mengkonversi limbah organik secara intensif menjadi kumpulan mikro-organisme yang berbentuk flok, kemudian flok tersebut dimanfaatkan oleh organisme akuatik sebagai pakan alami (Adharani et al. 2016; Avnimelech, 2012; de Schryver et al. 2009), sehingga selain dapat memperbaiki kualitas air, bioflok juga dapat meningkatkan efisiensi pakan yang berpengaruh terhadap penambahan bobot pada organisme akuatik (Avnimelech 2007; Crab et al. 2008).Manfaat lainnya adalah pemanfaatan sumber daya alam seperti air dan lahan yang terbatas, hal tersebut merupakan adaptasi dari beberapa cara pemeliharaan organisme akuatik dalam meningkatkan produksi budidaya (Suprapto dan Samtafsir 2013).

Flok terdiri dari beberapa mikro dan makro organisme pembentuk dan partikel tersuspensi yang berpengaruh terhadap struktur dan konsentrasi nutrisi pada flok, namun komunitas bakteri merupakan mikro-organisme paling dominan didalamnya (Jorand et al.1995; de Schryver et al. 2008). Dewasa ini, kandungan bakteri pada probiotik (konsorsium) komersial yang sering diperjual belikan untuk mendukung budidaya dengan sistem bioflok antara lain Bacillus subtilis, Bacillus lichenoformis, Bacillus pumilus (Zao et al. 2012); Bacillus megaterium, Bacillus aquimaris (Adharani et al. 2016); Otari dan Gosh 2009). Adharani et al. (2016) menegaskan bahwa jenis Bacillus sp. merupakan bakteri heterotrof yang memiliki performa baik dalam perbaikan kualitas air melalui sistem bioflok. 
Dalam uji coba yang dilakukan, komoditas biota yang digunakan adalah udang vaname, pemilihan udang vaname karena merupakan produksi budidaya terbesar di Kabupaten Banyuwangi (DPP Kabupaten Banyuwangi 2016). Disisi lain udang vaname membutuhkan pakan dengan konsentrasi protein yang tinggi, sehingga akan berdampak pada tingginya bahan organik yang dihasilkan baik dalam media air maupun buangan limbah yang akan dikeluarkan sehingga memerlukan pengelolaan kualitas air yang baik dalam mengoptimalkan pertumbuhan udang. Tentunya penggunaan molase (tetes tebu) sebagai sumber karbon bakteri dan pemasangan aerasi sebagai pemasok oksigen dilakukan dalam penelitian ini. Penelitian yang dilakukan ini menggunakan isolasi bakteri hidrokarbonoklastik yang ditemukan daari sedimen mangrove tercemar minyak bumi di Cilacap, Jawa Tengah (Syakti et al. 2013) yaitu Bacillus megaterium dan Bacillus aquimaris. Terdapat 4 perlakuan dengan 3 ulangan diantaranya, kontrol (P1); Bacillus megaterium (P2); Bacillus aquimaris (P3); Bacillus megaterium dan Bacillus aquimaris (P4).

\section{METODE}

Penelitian dilakukan dalam skala laboratorium, berikut adalah tahapannya :

1. Pembuatan probiotik: kedua bakteri di remajakan terlebih dahulu menggunakan media Tripcase Soy Agar (TSA) dan pembuatan media cair atau probiotik menggunakan media Nutrient Broth (NB) dengan lama kultivasi selama 72 hari

2. Uji coba dilakukan menggunakan toples plastik berbentuk bundar seabagai wadah budidaya dengan kapasitas $16 \mathrm{~L}$.

3. Hasil penelitian dipusatkan pada penurunan limbah kualitas air sebagai parameter utama, diantaranya amonia, nitrat, dan nitrit. Parameter pendukung diantaranya, oksigen terlarut, suhu, salinitas, dan pH. Didukung dengan performa udang yakni melalui perhitungan panjang dan bobot udang menggunakan mistar dan timbangan analitik. Uji kualitas air dilakukan setiap 1x dalam seminggu selama 42 hari sedangkan performa udang dengan cara sampling pada minggu awal tebar dan minggu akhir penelitian.

Benur udang yang digunakan berumur 3 minggu dan ditebar sebanyak 32 ekor serta dibudidaya secara super intensif, karena kegiatan yang dilakukan dalam skala laboratorium maka perlakuan yang dilakukan secara terkontrol. Seperti pemberian pakan, perlakuan tanpa sistem bioflok diberikan pakan sebanyak 2 kali sehari dengan 
feeding rate $5 \%$ pada pagi hari dan $3 \%$ pada sore hari dari biomassa bobot udang, sedangkan perlakuan dengan sistem bioflok diberikan pakan dengan feeding rate 3\% pada pagi hari dan $2 \%$ pada sore hari dari biomassa bobot udang. Waktu lama pemeliharaan udang selama selama 42 hari dengan pemberian molase sebanyak 0,1 $\mathrm{ml} / \mathrm{l}$ selama sekali dalam seminggu (Adharani et al. 2016).

\section{Parameter Uji dan Analisis Data}

Parameter utama diantaranya: analisis amonia, nitrat, nitrit dan paramter pendukung seperti suhu, salinitas, $\mathrm{pH}$ dan oksigen terlarut dilakukan setiap satu kali dalam seminggu. Pengujian terhadap performa ikan yaitu panjang dan bobot udang dilakukan pengukuran diawal adan akhir penelitian. Data yang terkumpul akan dianalisis menggunakan SEM (Standart Error Mean) dengan software Microsoft excel 2013. Kemudian data dideskripsikan menggunakan grafik di setiap hasil parameter uji ditiap perlakuan.

\section{HASIL DAN PEMBAHASAN}

Berikut adalah uji coba yang dilakukan

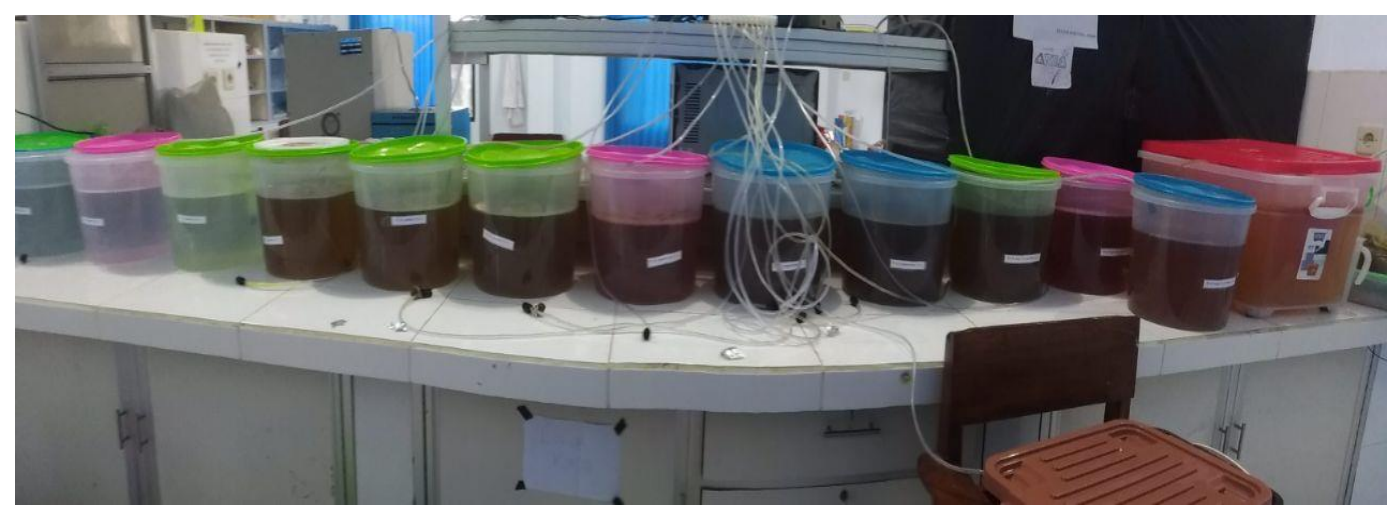

Gambar 1. Uji Coba Penelitian

\section{Amonia}




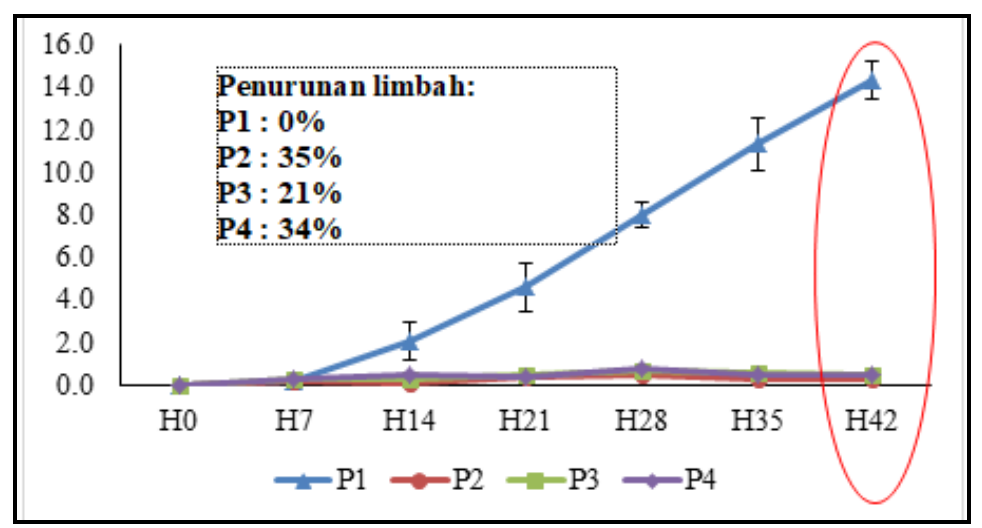

Gambar 2. Perubahan amonia pada penelitian $(\mathrm{mg} / \mathrm{L})$

Gambar 2 diatas menunjukkan bahwa pada H42 terlihat perbedaan antara seluruh perlakuan bioflok dan non bioflok, penurunan yang paling optimal adalah P2 sebesar 0,3 mg/L disusul dengan P4 dan P3 dengan penurunan amonia sebesar 0,5 mg/L, sedangkan P1 menghasilkan nilai amonia sebesar 14,3 mg/L. Melalui data statistik, seluruh perlakuan selain P1, saling bersinggungan yang artinya tiap perlakuan tidak berbeda nyata sedangkan perlakuan P1 dengan perlakuan lainnya yaitu berbeda nyata. Kenaikan konsentrasi amonia yang terus meningkat pada P1 dikarenakan tidak adanya proses dekomposisi limbah organik oleh bakteri pengurai (sistem bioflok), amonia tersebut berasal dari sisa ekskresi dan sisa pakan yang mengendap sehingga hasil akhirnya berupa konsentrasi amonia yang tinggi dan bau tidak sedap pada P1. Rendahnya konsentrasi amonia pada P2 sesuai dengan standar baku optimalnya pertumbuhan udang yakni maksimal 0,3 mg/L (KLH tahun 2014) didukung pernyatan JIFSAN, (2007) bahwa udang vaname akan mati jika konsentrasi amonia >2 mg/L. Adharani et al. (2006) menjelaskan bahwa bakteri dari golongan Bacillus dapat menghasilkan enzim urease yang mampu merubah amonia menjadi amonia karbonat selanjutnya akan terus diurai oleh bateri menjadi karbondioksida dan air, sehingga penurunan amonia yang terjadi pada sistem bioflok terjadi secara optimal.

\section{Nitrat}




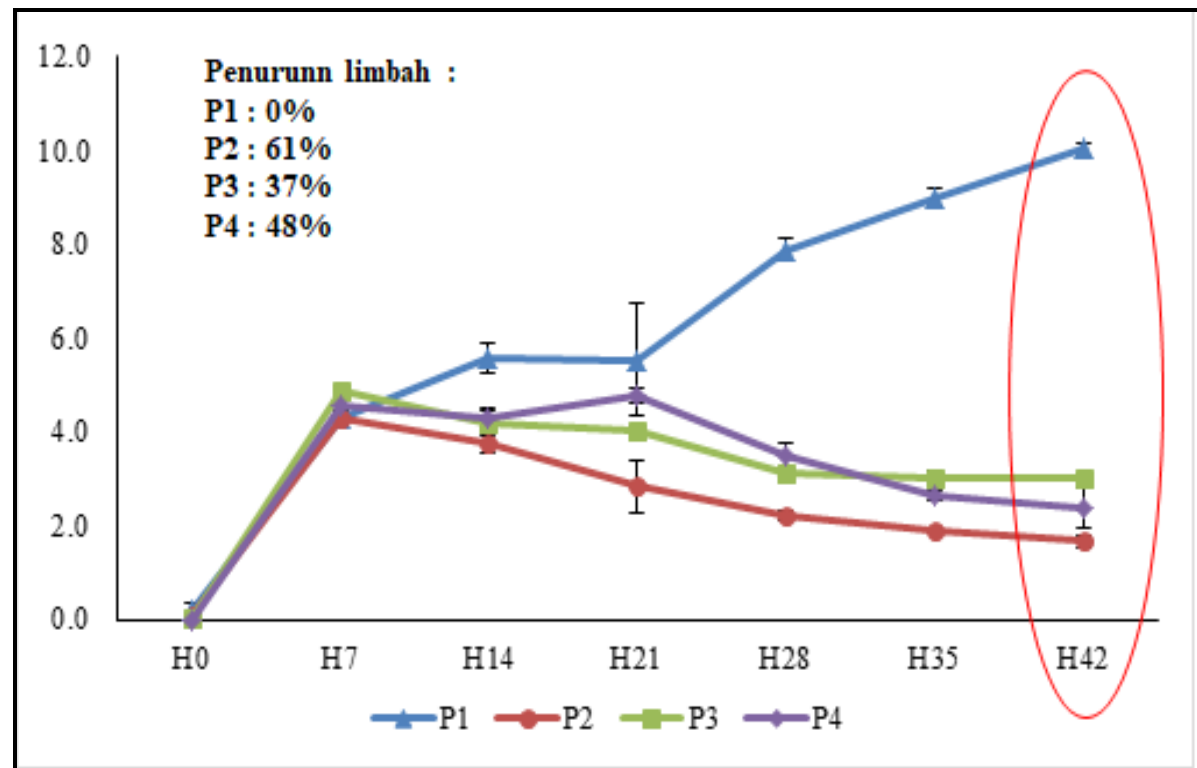

Gambar 3. Perubahan nitrat pada penelitian $(\mathrm{mg} / \mathrm{L})$

Gambar 2 diatas menunjukkan bahwa konsentrasi nitrat mulai meningkat ditiap perlakuan mulai H0 higga $\mathrm{H} 7$, namun pada $\mathrm{H} 14$ konsentrasi nitrat mulai menurun kecuali pada P1. Diakhir pengamatan seluruh perlakuan selain P1 menghasilkan konsentrasi nitrat sebesar <3.1 mg/L. P1 menghasilkan konsentrasi paling besar yakni $10 \mathrm{mg} / \mathrm{L}$, sedangkan konsentrasi terendah terjadi pada P2 yaitu sebesar $1.67 \mathrm{mg} / \mathrm{L}$ dengan prosentase penurunan terbesar dibandingkan perlakuan lainnya yakni sebesar $61 \%$ disusul $\mathrm{P} 4$ dengan penurunan hingga $2.4 \mathrm{mg} / \mathrm{L}$ dengan prosentase punuruan sebesar 48\%. Menurut Mangampa et al. (2007) bahwa konsentrasi nitrat yang mendukung kegiatan budidaya udang sebesar 0.4-0.8 mg/L, sehingga konsentrasi nitrat yang dihasilkan seluruh perlakuan melebihi ambang batas optimalnya kelangsungan hidup udang, namun bila penggunaan bakteri terus menerus diberikan, dimungkinkan akan memperoleh kondisi yang optimal dalam kegiatan budidaya udang guna menghasilkan pertumbuhan yang besar. Hubungan positif antara bahan organik dengan total bakteri (B. megaterium) dikarenakan adanya proses deaminasi, dimana terjadi proses perombakan amonia menjadi karbondioksida dan air dalam perairan (Waluyo, 2004; George et al. 2011; Adharani et al. 2016).

\section{Nitrit}




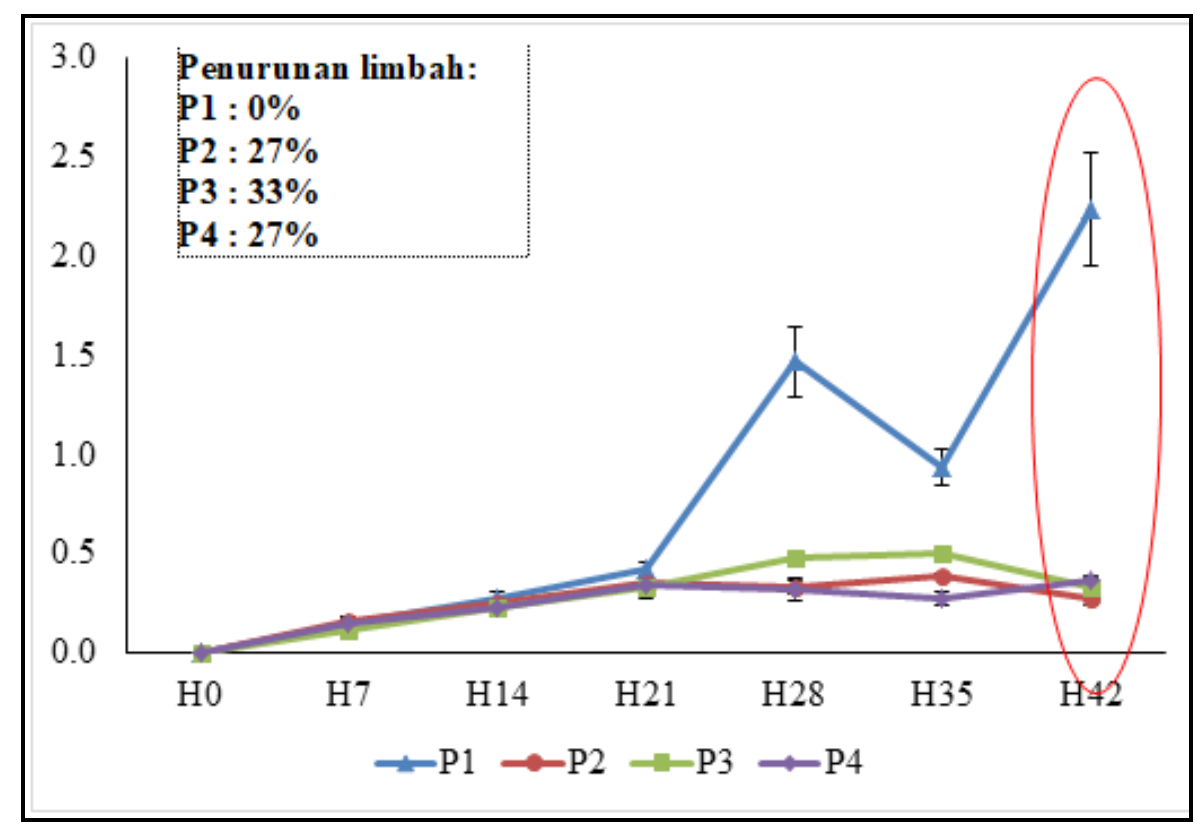

Gambar 4. Perubahan nitrit pada penelitian $(\mathrm{mg} / \mathrm{L})$

Nitrit merupakan proses biologis perombakan bahan organik bentuk peralihan antara amonia dan nitrat (nitrifikasi) dan antara nitrat dengan nitrogen (denitrifikasi). Konsentrasi nitrit yang dihasilkan cenderung mengalami peningkatan di H14, bahwa diakhir pengamatan seluruh perlakuan kecuali P1 memperoleh konsentrasi nitrit sebesar $<0.5 \mathrm{mg} / \mathrm{L}$. Pada P1 terjadi kenaikan konsentrasi yang fluktuatif karena kenaikan yang terjadi di H28 kemudian mengalami penurunan di H35 kemudian meningkat kembali mencapai $2.2 \mathrm{mg} / \mathrm{L}$. Penurunan konsentrasi nitrit terbaik di akhir pengamatan adalah P2 dengan konsentrasi sebesar $0.28 \mathrm{mg} / \mathrm{L}$ dengan prosentase penurunan sebesar $27 \%$, prosentase tersebut merupakan hasil awal pengamatan terhadap nitrit dikurangi hasil akhir dan dikalikan $100 \%$. Konsentrasi nitrit yang dihasilkan oleh B. megaterium telah memenuhi standar baku mutu yang ditetapkan oleh Amri (2008) yaitu sebesar >0,5 mg/L, serupa dengan penelitian Adharani et al. (2016) bahwa B. megaterium dapat menurunkan konsentrasi nitrit pada air limbah budidaya sebesar 0,055 mg/L, hal tersebut merupakan penrunan nitrit optimal dibandingkan perlakuan lainnya.

\section{Parameter Lingkungan}


Tabel 1. Parameter Lingkungan Air Budidaya Udang Vanamei Pada Penelitian

\begin{tabular}{lccccc}
\hline \multirow{2}{*}{ Parameter } & \multicolumn{4}{c}{ Perlakuan } & $\begin{array}{c}\text { Standar Baku } \\
\text { Mutu (SNI 2006) }\end{array}$ \\
\cline { 2 - 5 } & $\mathrm{P} 1$ & $\mathrm{P} 2$ & $\mathrm{P} 3$ & $\mathrm{P} 4$ & $25-31.5$ \\
\hline Suhu & $25-28^{\circ} \mathrm{C}$ & $28-31^{\circ} \mathrm{C}$ & $26-31^{\circ} \mathrm{C}$ & $26-30^{\circ} \mathrm{C}$ & $15-40$ \\
\hline Salinitas & $35-39 \mathrm{ppt}$ & $35-39 \mathrm{ppt}$ & $35-40 \mathrm{ppt}$ & $35-39 \mathrm{ppt}$ & $7.5-8.5$ \\
\hline $\mathrm{pH}$ & $6.0-8.0$ & $6.7-8.2$ & $6.8-7.2$ & $6.7-8.1$ & $>3.5$ \\
\hline Oksigen terlarut & $6.5-12.2$ & $5.4-10$ & $6.1-10.9$ & $6.0-10.6$ & \\
\hline
\end{tabular}

Hasil konsentrasi parameter lingkungan seperti suhu, salinitas, $\mathrm{pH}$, dan oksigen terlarut ditiap perlakuan berada dalam batas yang layak bagi pertumbuhan udang menurut SNI Tahun 2016.

\section{Panjang dan Bobot Udang}

Performa budidaya biota akuatik dapat dilihat dari pertumbuhannya. Pertumbahan yang diamati adalah pertambahan bobot dan panjang pada udang vanamei, pengamatan dilakukan diakhir pengamatan yakni di hari ke-42. Hasil yang diperoleh bahwa tiap perlakuan mengalami peningkatan seiring berjalannya waktu pemeliharaan. Pemeliharaan udang secara intensif disetiap perlakuan, nampak bahwa pertumbuhan udang tumbuh secara normal hingga akhir penelitian. Dapat dilihat pada Gambar 6 dibawah ini:

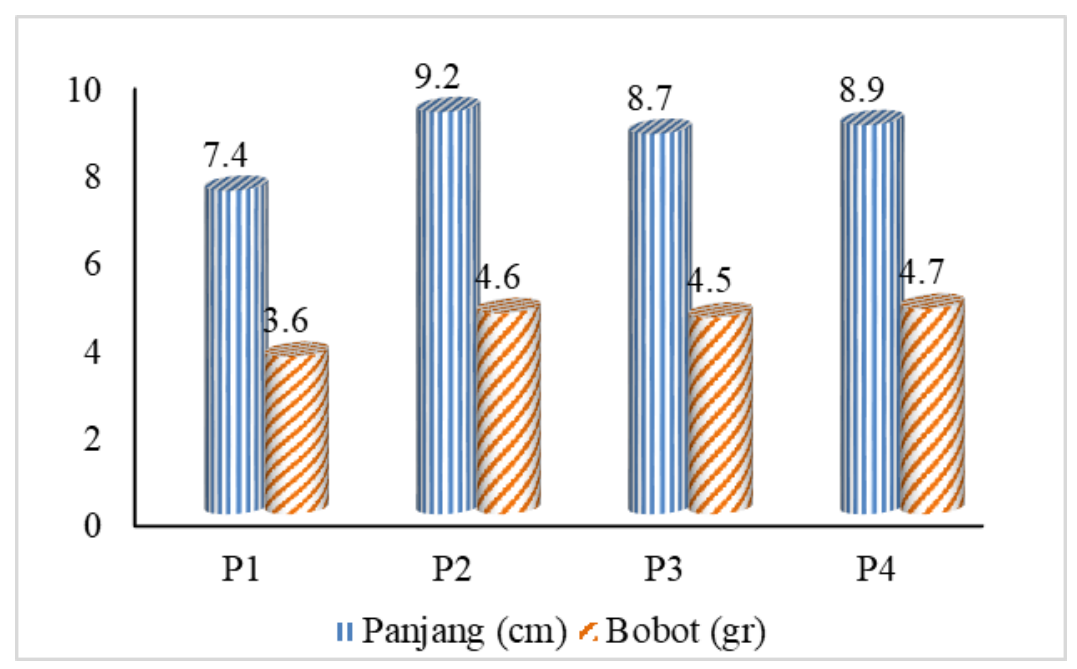

Gambar 5. Panjang dan Bobot Pada Udang di H42

Besarnya bobot udang di setiap perlakuan selain P1 (kontrol) mengindikasi bahwa dengan penerapan bioflok, keberadaan mikrobial dalam flok sebagai pakan alami dan 
energi yang diperoleh udang dimanfaatkan secara optimum (Assaduzzaman et al. 2008). Didukung dengan pernyataan Fujaya (2004) bahwa energi yang dihasilkan digunakan untuk metabolisme basal, aktivitas dan pertumbunan. Proses bioflok sebagai upaya pembentukan bioflok sebagai sumber pakan bagi udang. Penambahan molase sebagai sumber karbon bagi bakteri menyebabkan flok yang terbentuk mengandung jumlah protein yang tinggi di bandingkan lemak, hal ini mempengaruhi bahwa bioflok dapat memberikan nutrisi penting untuk meningkatkan kinerja bagi pertumbuhan udang (Crab et al 2007).

Gambar 6. Perbandingan Panjang Udang Bioflok dan Tradisional

\section{KESIMPULAN DAN SARAN}

Penggunaan bakteri Bacillus megaterium dan Bacillus aquimaris dalam sistem bioflok lebih efektif dibandingkan perlakuan non bioflok dalam mengelola kualitas air budidaya udang vaname. Perlakuak P2 dengan pemanfaatan B. megaterium paling efektif dalam penurunan amonia sebesar 35\%, penurunan nitrat sebesar $61 \%$ dan penurunan nitrit sebesar 27\%. Disusul dengan P4 dengan penggunaan B. megaterium dan $B$. aquimaris dalam menurunkan limbah organik dengan prosentase penurunan amonia sebesar 34\%' prosentase penurunan nitrat sebesar 48\%, dan prosentase penurunan nitrtit sebesar $27 \%$. Hasil uji peerforma udang melalui proses bioflok lebih efektif dan berpengaruh terhadap panjang dan bobot pada udang dibandingan tanpa sistem bioflok. Bahwa P2 menghasil panjang dan bobot yang lebih besar diantara 
perlakuan lainnya yakni dengan rata-rata panjang sebesar $9.2 \mathrm{~cm}$ dan rata-rata bobot sebesar 4.6 gr.

\section{DAFTAR PUSTAKA}

[JIFAN] Joint Institut for Food Safety and Applid Nutrition. 2007. Growout Pound and Water Quality Management. University of Maryland:JIFSAN.

Adharani A, Soewardi K, Syakti AD, Haryadi S. 2016. Manajemen Kualitas Air Dengan Teknologi Bioflok : Studi Kasus Pemeliharaan Ikan Lele (Clarias sp.). Jurnal Ilmu Pertanian Indonesia. 21 (1) : 35-40

Adharani A, Soewardi K, Syakti AD, Haryadi S. The Quality of Nutrients Floc to Performance Catfish in Technology Biofloc. 2016. Proceeding International Seminar and Expo On Sustainable Utilization of Coastal Resources in Tropical Zone. 165-173.

Amri K, Iskandar K. 2008. Budidaya udang vaname secara intensif, semi intensif dan tradisional. Jakarta. Gramedia Pustaka Utami.

Avnimelech Y. 2007. Feeding With Microbial Flocs By Tilapia In Minimal Discharge Bio-Flocs Technology Ponds. Aquaculture. 264: 140-147.

Avnimelech Y. 2012. Biofloc Technology-a Practical Guide Book, 2nd edition. United States: The World Aquaculture Society.

Crab R, Kochva M, Verstraete W, Avnimelech Y. 2008. Bio-Flocs Technology Application In Over-Wintering Of Tilapia. Aquaculture Engineering. 40 : 105112.

De Schryver PD, Crab R, Defoirdt T, Boon N, Verstraete W. 2008. The Basics Of Bioflocs Technology: The Added Value For Aquaculture. Aquaculture. 277: 125137

Fujaya Y. 2004. Fisiologi Ikan. Rineka Cipta, Jakarta.

George M, Cyriac N, Nair A, Hatha AAM. 2011. Diversity of Bacillus and Actinomycetes in the water and sediment samples from Kumarakom region of Vembanadu lake. Indian Journal of Geo-Marine Sciences. 40(3) : 430-437.

Mangampa M, Suwoyo H.S, Rahmansyah. 2009. Dinamika kualitas air pada budidaya intensif udang vaname (Litopenaeus vannamei) dengan kedalaman air tambak yang berbeda. Forum Inovasi Teknologi Akuakultur. 17 Halaman. 
Jorand F, Zartarian F, Thomas F, Block J C, Bottero J Y, Villemin G, Urbain V, Manem J. 1995. Chemical And Structural (2d) Linkage Between Bacteria Within Activated Sludge Flocs. Water Resources. 29 (7) : 1639-1647.

Otari SV, Ghosh JS. 2009. Production and characterization of the polymer Polyhydroxybutyrate-co-polyhydroxyvalerat by Bacillus megaterium NCIM 2475. Current Research Journal of Biological Sciences. 1(2): 23-26.

Putra S J W, Nitisuparji M, Widyorini N. 2014. Analisis hubungan bahan organik dengan total bakteri pada tambak udang intensif sistem bioflok di BBPBAP Jepara. Diponegoro Journal of Maquares. 3(3):121-129

Suprapto, Samtafsir SL. 2013. Biofloc-165 Rahasia Sukses Teknologi Budidaya Lele. AGRO 165, Depok.

Syakti AD, Yani M, Hidayati NV, Siregar AS, Doumenq P, Sudiana MM. 2013. The Bioremediation Potential Of Hydrocarbonoclastic Bacteria Isolated From A Mangrove Contaminated By Petroleum Hydrocarbons On The Cilacap Coast, Indonesia. Bioremediation Journal. 17(1) : 11-20.

Waluyo L. 2004. Mikrobiologi Umum. Universitas Muhammadiyah Malang Press, Malang. 